\title{
Estimation of rate of protein synthesis by constant infusion of labelled amino acids in pigs
}

\author{
BY O. SIMON, R. MÜNCHMEYER AND H. BERGNER \\ Institute of Animal Nutrition, Department of Animal Production and \\ Veterinary Medicine, Humboldt University, Berlin, German Democratic Republic \\ AND TERESA ŻEBROWSKA AND LUCYNA BURACZEWSKA \\ Institute of Animal Physiology and Nutrition, Jabłonna, Warsaw, Poland
}

(Received I I October 1977 - Accepted 8 February 1978)

I. The fractional synthetic rates of tissue proteins were studied in growing pigs using the constant-infusion technique of tracer-labelled amino acids ([$\left.{ }^{14} \mathrm{C}\right]$ leucine and $\left[{ }^{14} \mathrm{C}\right]$ lysine) and the mathetmatical model for calculation, employed in rats by Garlick, Millward \& James (I973).

2. During a $6 \mathrm{~h}$ infusion, samples were taken from blood and muscle and at the end of the infusion from liver, muscle, pancreas, heart, duodenum, jejunum, ileum, colon, and skin. The specific radioactivity of free and protein-bound leucine and lysine was estimated.

3. A quasi-steady-state in the specific radioactivity of free plasma leucine and lysine was reached within approximately $2 \mathrm{~h}$, the rate-constants being 35 and $48 / \mathrm{d}$ respectively.

4. The specific radioactivity of free leucine and lysine in plasma was used to calculate the flux of these amino acids. It was found to be higher than the daily intake.

5. The average fractional rate of protein synthesis in muscle and heart was $8.1 \% / \mathrm{d}$, in small and large intestine the values were 50 and $33 \% / \mathrm{d}$ respectively and in liver and pancreas more than $100 \% / \mathrm{d}$.

6. The calculation of protein synthetic rate in pig tissue using the constant-infusion method of labelled amino acids seems to be a suitable tool for study of this species.

In most instances the measurement of protein synthesis rates in vivo involves isotopic methods. Methods based on the uptake of isotopes by proteins, yielding information about the rate of protein synthesis demand the measurement of precursor specific activity (Millward, Garlick, James, Sender \& Waterlow, I976). The direct precursor for protein synthesis, aminoacyl-t-RNA, is technically difficult to determine. In addition, it is not known whether the $t$-RNA is charged exclusively with amino acids derived from the extracellular or from the intracellular pools (Airhart, Vidrich \& Khairallah, 1974). Consequently the specific activities of the free amino acids in either plasma or tissues have been used. Because of the rapid change in the specific activity of an amino acid after a single injection of label (Henriques, Henriques \& Neuberger, 1955; Simon, Münchmeyer, Bergner \& Żebrowska, 1976) a method was employed in which a plateau in the specific activity of free amino acids in plasma and tissue was reached using a continuous infusion of labelled amino acids (Waterlow \& Stephen, 1967, 1968; Garlick, 1969). A single measurement of the specific activity of protein-bound and free amino acids at the end of $6 \mathrm{~h}$ infusion was used to calculate the rate of protein synthesis (Garlick, Millward \& James, I973). This method was used mainly in studies of the rate of protein synthesis in rats (Millward \& Garlick, 1972; Millward, Nnanyelugo \& Garlick, 1974a, $b$; Millward, Garlick, Stewart, Nnanyelugo \& Waterlow, 1975; Millward, Garlick, Nnanyelugo \& Waterlow, 1976), but only a few estimates have been made for farm animals. In Perry's (I975) studies in which anaesthetized pigs received constant infusions of $\left[{ }^{14} \mathrm{C}\right]$ glycine and $\left[{ }^{3} \mathrm{H}\right]$ tyrosine, the plasma radioactivity had not reached a plateau after $8 \mathrm{~h}$ and it was not possible to calculate absolute rates of muscle protein synthesis. Garlick, Burk \& Swick ( 1976 ) used a continuous infusion of $\left[{ }^{14} \mathrm{C}\right]$ tyrosine 
in pigs for a period of $6 \mathrm{~h}$. In this experiment they reached a plateau in plasma specific radioactivity of free tyrosine and calculated the rate of protein synthesis in various tissues.

In the present experiments the rate of protein synthesis in different tissues of pigs was measured by constant simultaneous infusion of $\left[{ }^{14} \mathrm{C}\right]$ leucine and $\left[{ }^{14} \mathrm{C}\right]$ lysine. The method of calculating rates of protein synthesis described by Garlick et al. (1973) was applied.

\section{EXPERIMENTAL}

Animals and diets. The experiment was carried out on three Polish Landrace castrated male pigs of approximately $30 \mathrm{~kg}$ body-weight. Catheters were implanted into the jugular vein and into the carotid artery of each animal. The animals were given twice daily $700 \mathrm{~g}$ of a barley-fish meal diet containing I $70 \mathrm{~g}$ crude protein (nitrogen $\times 6 \cdot 25$ ) $/ \mathrm{kg}$. (Composition of the diet $(\mathrm{g} / \mathrm{kg}$ ) : barley 867 , fish meal Ioo, vitamin-mineral mixture (Polfamix L) (Harenza, Wojtatowicz \& Zouner, I975) $20, \mathrm{CaCO}_{3} \mathrm{IO}, \mathrm{NaCl} 5$ ).

Isotope administration and collection of samples. At $6 \mathrm{~h}$ after a morning feed arterial infusion of $\mathrm{L}-\left[{ }^{14} \mathrm{C}\right]$ leucine and $\mathrm{L}-\left[{ }^{14} \mathrm{C}\right]$ lysine (UVVR, Prague, Czechoslovakia) in sterile saline $(9 \mathrm{~g} \mathrm{NaCl} / 1)$ was started at a rate of $4.2 \mathrm{ml}$ of each isotope/h using a peristaltic pump (Technicon Instruments Co. Ltd, Basingstoke, Hants, UK). The specific activity of L-[U-14 C]leucine was $210 \mathrm{mCi} / \mathrm{mmol}$ and that of $\mathrm{L}-\left[\mathrm{U}-{ }^{14} \mathrm{C}\right]$ lysine was $180 \mathrm{mCi} / \mathrm{mmol}$. The concentration of radioactivity in both solutions infused was $30 \mu \mathrm{Ci} / \mathrm{ml}$. The infusion lasted for $6 \mathrm{~h}$ and during the infusion period samples of blood $(5 \mathrm{ml})$ were taken every $30 \mathrm{~min}$ from the jugular vein. Samples of musculus gastrocnemius were obtained throughout the infusion at 20,60, 130 and $240 \mathrm{~min}$. The samples $(\mathrm{I}-2 \mathrm{~g})$ were removed after the incision and separation of overlying skin, fat and connective tissue. Immediately after biopsy the wound was plugged with sterile gauze. Loss of blood using this technique was very small. Samples of liver were taken at 30,90 and 200 min after the start of infusion from one pig. The biopsy was carried out under temporary anaesthesia with Eunarcon (Riedel, Hannover, West Germany). At the end of the $6 \mathrm{~h}$ infusion period the animals were anaesthetized with Eunarcon, the infusion was continued and liver, gastrocnemius muscle, pancreas, kidney, heart, duodenum, jejunum, ileum, colon and skin were sampled rapidly, placed in known amounts of cold saline and immediately frozen in a bath containing solid carbon dioxide and acetone.

Preparation and analysis of samples. The samples of tissues were homogenized in ice-cold saline with an Ultra-Turrax homogenizer (TP $18 / 2$; Janke and Kunkel KG-IKA-Werk, D 78 3 Staufen, West Germany). Proteins of tissues and heparinized plasma were precipitated with trichloroacetic acid solution ( $100 \mathrm{~g} / \mathrm{l})$ (TCA). Protein precipitates were washed with TCA which was extracted from the combined supernatant fraction and washings with three portions of diethyl ether and the residual solution were prepared for amino acid analysis. The precipitates were hydrolysed with $6 \mathrm{M}$-hydrochloric acid for $3 \mathrm{~h}$ at $135^{\circ}$ under a pressure of $2.1 \times 10^{5} \mathrm{~N} / \mathrm{m}^{2}$, and were also prepared for amino acid analysis.

The specific radioactivity of protein-bound and free leucine and lysine was assayed. For this purpose the amino acids were separated on a $1400 \times 6 \mathrm{~mm}$ column with Chromobead type B resin (Technicon Instrument Co. Ltd) using an amino acid analyser (NP I; Technicon Instrument Co. Ltd). The effluent from the column was divided into two portions, one portion of approximately $15 \%$ for automated quantitative estimation of amino acid content and the second portion was collected in vials for the estimation of radioactivity content using a liquid-scintillation spectrometer (Tricarb Spectrometer 3380; Packard Instrument Co. Inc., Downers Grove, Ill. 60515, USA). Corrections for counting efficiency were made using an external standard procedure. Specific radioactivity was expressed as disintegrations/ min per $\mu \mathrm{mol}$. 
Calculations. The amino acid flux was calculated according to Millward, Garlick, James et al. (1976).

$$
Q=\frac{I . S_{i}}{S_{\text {pmax }}}
$$

where $Q$ is the flux rate $(\mu \mathrm{mol} / \mathrm{min}), I$ is the rate of amino acid infusion $(\mu \mathrm{mol} / \mathrm{min}), S_{i}$ is the specific radioactivity of infused amino acid $(\mu \mathrm{Ci} / \mu \mathrm{mol}), S_{\text {max }}$ is the specific radioactivity at plateau of the plasma amino acid in the steady-state $(\mu \mathrm{Ci} / \mu \mathrm{mol})$.

The fractional rate of protein synthesis was calculated according to the model given by Garlick et al. (1973). In this model the specific radioactivity of free plasma amino acid increased to a plateau by a pathway which can be described by a single exponential of the type:

$$
S_{i}=S_{\text {max }}\left(\mathrm{I}-e^{-\lambda p t}\right)
$$

where $S_{p}$ is the specific radioactivity of plasma amino acid, $S_{\text {pmax }}$ is the value of $S_{p}$ when the plateau had been reached, $\lambda p$ is the rate-constant, $t$ is the time.

The specific radioactivity of free amino acids in tissue $\left(S_{i}\right)$ can be expressed using the same type of equation.

The fractional rate of protein synthesis was estimated by solving the equation graphically:

$$
\frac{S_{B}}{S_{i}}=\frac{\lambda i}{\left(\lambda i-k_{s}\right)} \cdot \frac{\left(\mathrm{I}-e^{-k_{s} t}\right)}{\left(\mathrm{I}-e^{-\lambda i t}\right)}-\frac{k_{s}}{\left(\lambda i-k_{s}\right)},
$$

where $S_{i}$ is the specific radioactivity of the intracellular free amino acid at the end of the infusion, $S_{B}$ is the specific radioactivity of the protein-bound amino acid at the end of the infusion, $\lambda i$ is the rate-constant, $k_{s}$ is the fractional rate of protein synthesis. In our study the true $\lambda i$ value for muscle and heart of each animal was determined and it was used to calculate the corresponding $k_{s}$ values of muscle and heart proteins.

Based on the suggestions of Garlick et al. (1973) the values of $\lambda p$ were taken instead of $\lambda i$ for the calculations of $k_{s}$ values for other organs.

\section{RESULTS}

Specific radioactivity of free leucine and lysine in plasma and other tissues. The value for the specific activity of free leucine and lysine reach plateaux within $\mathrm{I}-2 \mathrm{~h}$ of infusion. An example of the specific activity of free leucine and lysine in plasma is shown in Fig. I. Transforming equation no. I for each point (shown in Fig. I) a set of twelve $\lambda p$ values were calculated and an average $\lambda p$ value was estimated. The $\lambda p$ values for both amino acids are presented in Table $I$. The specific activity of free leucine and lysine in gastrocnemius muscle increased to a plateau by a similar pathway to that in plasma; the mean $\lambda i$ values being somewhat lower than the mean $\lambda p$ values (see Fig. 2 and Table I). The mean $\lambda p$ or $\lambda i$ values were substituted in equation no. 2 and points for drawing the curve were calculated. As shown in Fig. I and 2, there was a close similarity between the calculated and actual lines. At the end of the infusion the relative specific activity of free leucine and lysine in tissues was lower than in plasma (Table 2). Among the different tissues the lowest values were found in liver.

The leucine and lysine flux rates. The flux rates of leucine and lysine were found to be approximately 200 and $70 \mu \mathrm{mol} / \mathrm{min}$ respectively (Table 3 ). It can be seen that the flux rate was similar for all animals. The flux rate for leucine exceeded intake by approximately $55 \%$ and for lysine by approximately $17 \%$.

The rate of protein synthesis. The estimate of the rate of the protein synthesis was 


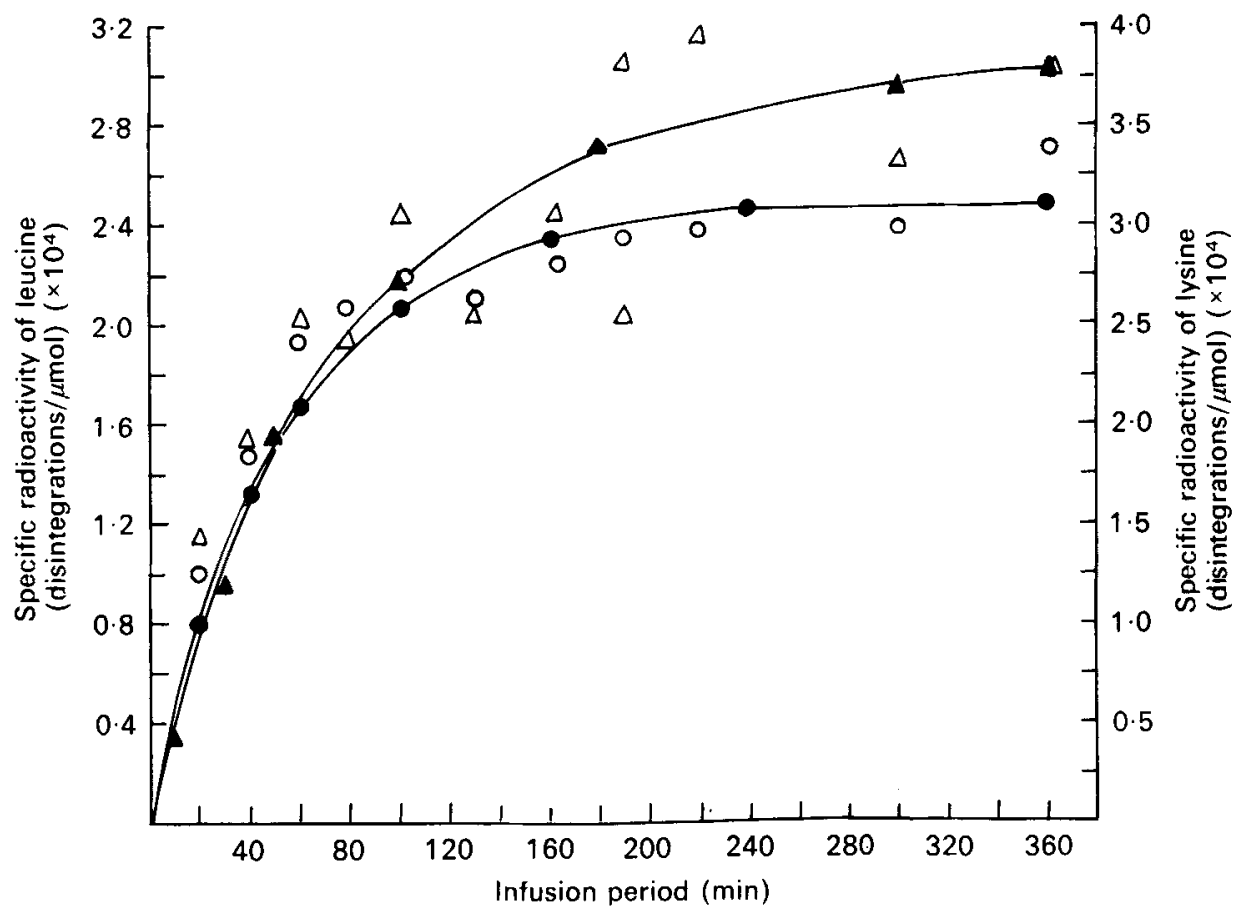

Fig. I. Specific radioactivity of free leucine and lysine in plasma samples from one pig during a $6 \mathrm{~h}$ continuous infusion of $\mathrm{L}-\left[{ }^{14} \mathrm{C}\right]$ leucine and $\mathrm{L}-\left[{ }^{4} \mathrm{C}\right] \mathrm{lysine}$; comparison of theoretical curves: $(\bullet)$, leucine, rate-constant $(\lambda p) 27.7 / \mathrm{d} ;(\Lambda)$, lysine, $\lambda p$ I 8.4/d and of the observed values: $(0)$, leucine; $(\triangle)$, lysine. For details of procedures, see p. 245.

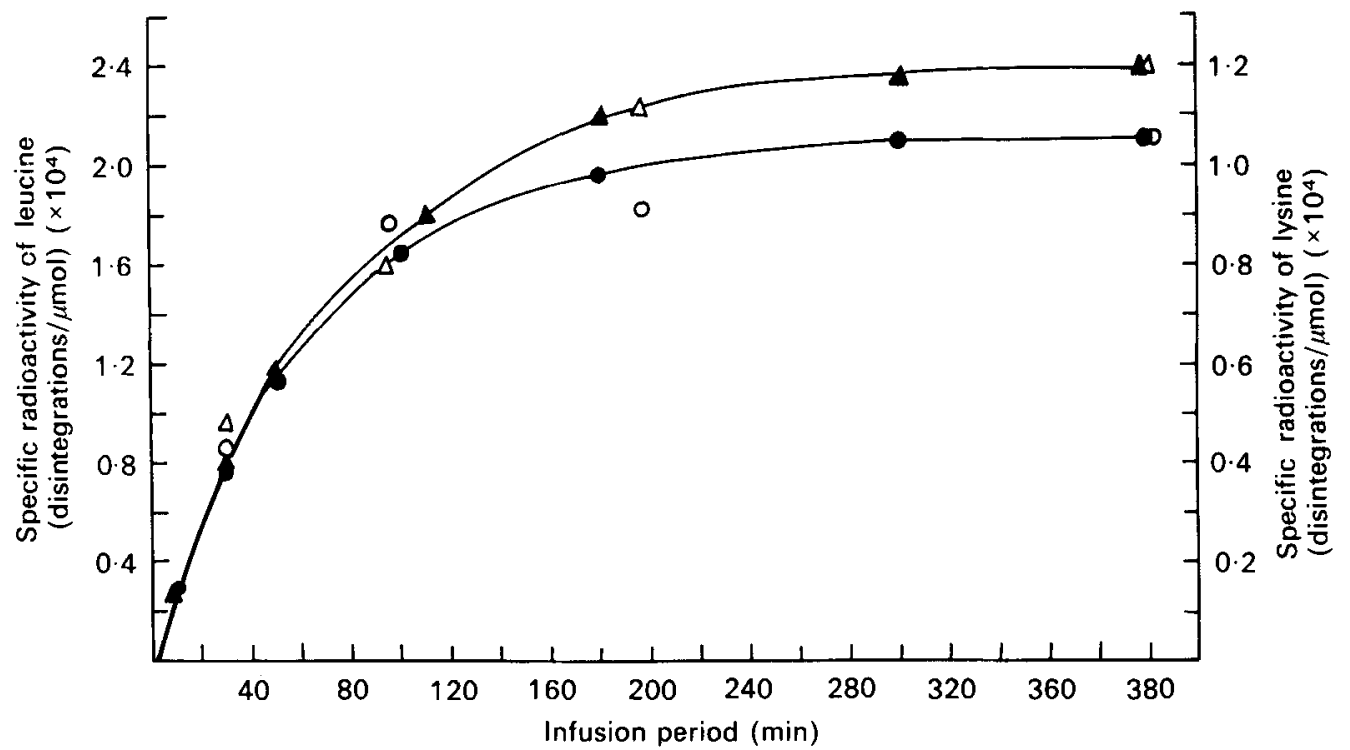

Fig. 2. Specific radioactivity of free leucine and lysine in the gastrocnemius muscle from one pig during a $6 \mathrm{~h}$ continuous infusion of $\mathrm{L}-\left[{ }^{14} \mathrm{C}\right]$ leucine and $\mathrm{L}-\left[{ }^{14} \mathrm{C}\right] l y$ sine; comparison of theoretical curves: (๑), leucine, rate-constant $(\lambda i)_{21} \cdot 7 / \mathrm{d} ;(\Delta)$, lysine, $\lambda i 19 \cdot 7 / \mathrm{d}$ and of the observed values: $(\bigcirc)$, leucine; $(\triangle)$, lysine. For details of procedures, see p. 245. 
Table $\mathrm{I}$. Rate-constants $(/ d)$ for the increase in specific radioactivity of free leucine and lysine in plasma and musculus gastrocnemius in pigs receiving a continuous infusion of $\mathrm{L}-\left[{ }^{14} \mathrm{C}\right]$ leucine and $\mathrm{L}-\left[{ }^{14} \mathrm{C}\right]$ lysine for $6 h^{*}$

(The rate-constants were calculated using equation no. 2 (p. 245) and based on the specific radioactivity of leucine and lysine during the $6 \mathrm{~h}$ continuous-infusion period)

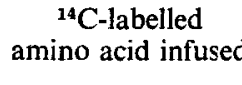

L-leucine

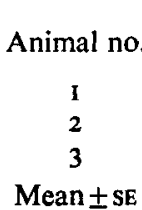

1
2
3

\begin{tabular}{ll}
\hline \multicolumn{2}{c}{ Rate constant } \\
\hline Plasma & $21 \cdot 7$ \\
27.7 & $20 \cdot 8$ \\
28.6 & $20 \cdot 8$ \\
$49 \cdot 0$ & $21 \cdot 1 \pm 0.3$ \\
$35 \cdot 1 \pm 6.9$ & 19.7 \\
18.4 & $11 \cdot 1$ \\
75.0 & 18.6 \\
50.4 & $16.5 \pm 2.7$ \\
$47.8 \pm 16.4$ &
\end{tabular}

* For details of procedures, see p. 245 .

Table 2. Relative specific radioactivity of free leucine and lysine in tissues at the end of a $6 \mathrm{~h}$ continuous infusion of $\mathrm{L}-\left[{ }^{14} \mathrm{C}\right]$ leucine and $\mathrm{L}-\left[{ }^{14} \mathrm{C}\right]$ lysine on pigs ${ }^{*}$

(Mean values with their standard errors for three pigs. The specific radioactivity of plasma free amino acids was given the value of unity and that of other organs has been expressed relatively)

\begin{tabular}{|c|c|c|c|c|}
\hline \multirow[b]{3}{*}{ Organ } & \multicolumn{4}{|c|}{ Relative specific radioactivity of free amino acid } \\
\hline & \multicolumn{2}{|c|}{ Leucine } & \multicolumn{2}{|c|}{ Lysine } \\
\hline & Mean & SE & Mean & SE \\
\hline Liver & 0.22 & 0.080 & 0.11 & 0.057 \\
\hline Pancreas & 0.57 & 0.032 & 0.48 & 0.013 \\
\hline Duodenum & 0.58 & 0.046 & 0.32 & 0.027 \\
\hline Jejunum & 0.57 & 0.058 & 0.18 & 0.040 \\
\hline Ileum & 0.60 & 0.055 & 0.22 & 0.023 \\
\hline Colon & 0.60 & 0.058 & 0.29 & 0.009 \\
\hline Kidney & 0.62 & 0.001 & 0.73 & 0.264 \\
\hline Musculus gastrocnemius & 0.58 & 0.062 & 0.25 & 0.021 \\
\hline Heart & $1 \cdot 03$ & 0.097 & 0.56 & 0.019 \\
\hline Skin & 0.43 & 0.068 & 0.23 & 0.012 \\
\hline
\end{tabular}

* For details of procedures, see p. 245.

calculated from the specific radioactivities of free and protein-bound leucine and lysine in the tissue by using equation no. 3 . The results for the fractional rate of protein synthesis $\left(k_{s}\right)$ are listed in Table 4 and are expressed as $\% / d$, i.e. the proportion of the protein mass which is replaced each day. The fractional rate of protein synthesis was found to be highest in liver ( $\mathrm{I} 15 \% / \mathrm{d})$ and in pancreas (II I \%/d) followed by intestinal tissues and lowest in heart and gastrocnemius muscle. Generally, there was a good agreement between $k_{s}$ values calculated from values for both $\mathrm{L}-\left[{ }^{14} \mathrm{C}\right]$ leucine and L- $\left[{ }^{14} \mathrm{C}\right]$ lysine except for some tissues with high rates of protein turnover.

When the extracellular amino acids (plasma) were taken as precursors for the intracellular protein synthesis the calculated rate of protein synthesis was much lower because of the high specific radioactivity of free leucine and lysine in plasma. Thus the $k_{*}$ values calculated 
Table 3. Leucine and lysine flux ( $\mu \mathrm{mol} / \mathrm{min})$ in pigs with a body-weight of approximately $30 \mathrm{~kg}$ receiving a continuous infusion of $\mathrm{L}-\left[{ }^{14} \mathrm{C}\right]$ leucine and $\mathrm{L}-\left[{ }^{14} \mathrm{C}\right]$ lysine for $6 \mathrm{~h}^{*}$

(The values were calculated according to equation no. I (p. 245) based on the specific radioactivity of plasma free leucine and lysine at the end of the $6 \mathrm{~h}$ continuous-infusion period)

$\begin{array}{ccc}\text { Animal no. } & \text { Leucine } & \text { Lysine } \\ \text { I } & 202 & 76 \cdot 2 \\ 2 & 194 & 60.6 \\ 3 & 180 & 70 \cdot 0 \\ \text { Mean } \pm \text { SE } & 192 \pm 6.43 & 68.9 \pm 4.53 \\ \text { Daily amino acid flux }(\mathrm{g} / \mathrm{kg} \text { per d) } & 1.21 & 0.48 \\ \text { Daily amino acid intake }(\mathrm{g} / \mathrm{kg} \text { per d) } & 0.55 & 0.39\end{array}$

* For details of procedures, see p. 245.

Table 4. Fractional rate $(\% / d)$ of protein synthesis $\left(\mathrm{k}_{s}\right)$ of tissues in growing pigs receiving a continuous infusion of $\mathrm{L}-\left[{ }^{14} \mathrm{C}\right]$ leucine and $\mathrm{L}-\left[{ }^{14} \mathrm{C}\right]$ lysine for $6 h^{*}$

(Mean values with their standard errors for $k_{s}$, for three pigs for each labelled amino acid estimated separately or together. The infusion was continued after this $6 \mathrm{~h}$ period and tissue samples were taken rapidly under anaesthesia. The specific radioactivity of free and protein-bound leucine and lysine was determined and the protein synthesis rate was estimated by using equation no. 3 (p. 245))

Fractional protein synthesis rate estimated with:

\begin{tabular}{|c|c|c|c|c|c|c|}
\hline \multirow[b]{2}{*}{ Organ } & \multicolumn{2}{|c|}{ L- $\left[{ }^{14} \mathrm{C}\right]$ leucine } & \multicolumn{2}{|c|}{ L- $\left[{ }^{14} \mathrm{C}\right]$ lysine } & \multicolumn{2}{|c|}{$\begin{array}{c}\mathrm{L}-\left[{ }^{14} \mathrm{C}\right] \text { leucine }+ \\
\text { L- }\left[{ }^{14} \mathrm{C}\right] \text { lysine }\end{array}$} \\
\hline & Mean & SE & Mean & SE & Mean & SE \\
\hline Liver & 103 & $27 \cdot 8$ & 123 & 48 & I I 5 & 24 \\
\hline Pancreas & 141 & $21 \cdot 7$ & $8 \mathrm{I}$ & 23 & III & 20 \\
\hline Duodenum & 71 & $14 \cdot 8$ & 44 & 3.9 & 57 & $9 \cdot 2$ \\
\hline Jejunum & 45 & $3 \cdot 2$ & 68 & $8 \cdot 1$ & 57 & $6 \cdot 4$ \\
\hline Ileum & 35 & $3 \cdot 1$ & 39 & $1 \cdot 7$ & 37 & $1 \cdot 8$ \\
\hline Small intestine ${ }^{\dagger}$ & $5 I$ & $7 \cdot 0$ & 50 & $5 \cdot 2$ & & \\
\hline Colon & 34 & $2 \cdot 3$ & 32 & $2 \cdot 3$ & 33 & $1 \cdot 8$ \\
\hline Kidney & 37 & $5 \cdot 2$ & 17 & $4 \cdot 6$ & 27 & $5 \cdot 4$ \\
\hline Musculus gastrocnemius & $7 \cdot 6$ & $1 \cdot 0$ & $8 \cdot 6$ & 0.7 & $8 \cdot I$ & 0.6 \\
\hline Heart & $8 \cdot 9$ & 0.7 & $7 \cdot 3$ & $1 \cdot 3$ & $8 \cdot I$ & 0.8 \\
\hline Skin $\ddagger$ & 13 & & 20 & & 16 & 3.6 \\
\hline
\end{tabular}

from $\left[{ }^{14} \mathrm{C}\right]$ leucine values were two to three times higher than those calculated from $\left[{ }^{14} \mathrm{C}\right]-$ lysine values. For this reason the results are not presented.

\section{DISCUSSION}

It has been suggested that in species much larger than rats or mice, it takes considerably longer to reach plateau values of specific radioactivity for plasma free amino acids during infusion of labelled amino acids (Perry, 1975; Waterlow, 1967). Therefore it seemed important to study the time-course of specific radioactivity for free $\left[{ }^{14} \mathrm{C}\right]$ leucine and $\left[{ }^{14} \mathrm{C}\right]$ lysine in pigs. It can be seen (Fig. I) that the specific radioactivity of both amino acids in plasma increased to a plateau in a very similar way to that described for rats by Waterlow \& Stephen (1967). The average rate-constants (Table I) of 35/d and $48 / \mathrm{d}$ for leucine and lysine respectively are close to that for tyrosine of 50/d (Garlick et al. 1976) and even higher than 
Table 5. Distribution pattern among the tissues of the fractional rate of protein synthesis $\left(\mathrm{k}_{\mathrm{s}}\right)$ (calculated as \%/d and expressed relative to value for liver) calculated from $\left[{ }^{14} \mathrm{C}\right]$ leucine and $\left[{ }^{14} \mathrm{C}\right]$ lysine values and of the specific radioactivities (calculated as disintegrations/min per mol and expressed relative to values for liver) of these amino acids in mixed proteins at the end of a 6 continuous-infusion period*

\begin{tabular}{|c|c|c|c|c|}
\hline \multirow[b]{2}{*}{ Tissue } & \multicolumn{2}{|c|}{$\left[{ }^{14} \mathrm{C}\right]$ leucine } & \multicolumn{2}{|c|}{$\left[{ }^{14} \mathrm{C}\right]$ lysine } \\
\hline & $k_{\mathrm{a}}$ & $\begin{array}{c}\text { Specific } \\
\text { radioactivity }\end{array}$ & $k_{s}$ & $\begin{array}{c}\text { Specific } \\
\text { radioactivity }\end{array}$ \\
\hline Pancreas & $I \cdot 36$ & 3.68 & 0.64 & $4 \cdot 68$ \\
\hline Duodenum & 0.69 & $2 \cdot 25$ & 0.35 & 1.65 \\
\hline Jejunum & 0.44 & $I \cdot 34$ & 0.54 & $1 \cdot 45$ \\
\hline Ileum & 0.34 & $1 \cdot 05$ & 0.31 & 1.03 \\
\hline Colon & 0.33 & $I \cdot 04$ & 0.25 & $I \cdot I 4$ \\
\hline Kidney & 0.36 & $I \cdot 14$ & 0.13 & $1 \cdot 15$ \\
\hline Musculus gastrocnemius & 0.07 & 0.22 & 0.07 & 0.24 \\
\hline Heart & 0.09 & 0.46 & 0.06 & 0.45 \\
\hline Skin & 0.13 & $0 \cdot 27$ & $0 \cdot 16$ & 0.50 \\
\hline
\end{tabular}

* For details of procedures, see p. 245.

those reported for rats (I 2-24/d; Waterlow \& Stephen, 1967). With infusion of $\left[{ }^{14} \mathrm{C}\right]$ tyrosine into rats it has been shown that the plateau value was reached more rapidly, with a rateconstant of 80/d (Garlick et al. I973). In addition, in Table I it can be seen, that there were large variations between individuals in the rates at which the plateau value was reached. The variability was high throughout the increasing phase of the curve as well as at the plateau, an observation made also by Garlick et al. (1976) in experiments with pigs. This may be due to real fluctuations in specific radioactivity from minute to minute, as a result of changes in free amino acid concentrations.

Therefore, in organs where several samples were taken during the infusion it is probably more accurate to use a graphically determined or calculated value as the maximal specific activity of the free labelled amino acid in calculations and not simply values for the samples taken at the end of the infusion. In Perry's (1975) experiments using $\left[{ }^{14} \mathrm{C}\right]$ glycine and $\left[{ }^{3} \mathrm{H}\right]$ tyrosine in pigs $(24 \mathrm{~kg}$ live weight) no plateau was reached during $8 \mathrm{~h}$ of constant infusion for the radioactivity of deproteinized plasma. In these studies no specific radioactivity of the amino acid infused was measured and an accumulation of labelled $\mathrm{C}$ skeletons might have occured. Even for $\left[{ }^{14} \mathrm{C}\right]$ lysine infusion it has been demonstrated that the rate of increase in specific activity of free lysine was greater than that of radioactivity of the protein-free supernatant fraction (Waterlow \& Stephen, 1967). The specific radioactivity of free leucine and lysine in gastrocnemius muscle (Fig. 2) shows similar changes to those in plasma, with average rate-constants of $21 / \mathrm{d}$ and $16 \cdot 5 / \mathrm{d}$ for leucine and lysine respectively, the variations among the individuals being small (Table $I$ ).

Calculation of the theoretical curves (equation no. 2) using the estimated $\lambda p$ or $\lambda i$ values gave good agreement with the observed curves and supports the validity of the model for calculating the rates of protein synthesis in pigs.

Estimations of rate-constants for liver were available only from one animal, values being $17 / \mathrm{d}$ and $7 \cdot 4 / \mathrm{d}$ for leucine and lysine respectively. Lysine failed to reach a plateau within the $6 \mathrm{~h}$ infusion period. Using the proposals of Garlick et al. $(1973,1976)$ for the calculations of rates of protein synthesis for tissues with high protein turnovers (liver, intestine, pancreas) the $\lambda p$ values were used in preference to $\lambda i$ values. Flux is defined as the rate of exit of amino acid from a pool by synthetic as well as catabolic pathways. But in determining 
the flux of body free amino acids from plasma only a single homogenous pool is considered (Garlick et al. 1973; Millward, Garlick, James et al. 1976). This is not the situation for the intracellular pool because dilution by protein breakdown results in intracellular specific radioactivities less than in plasma (Table 2). Thus the flux of body free amino acids may be underestimated by the method used. In comparison to plasma the specific radioactivity of free leucine in tissues was approximately $60 \%$ and that of lysine only approximately $30 \%$ (Table 2). In particular the lysine flux may be underestimated. Because of this fact it is difficult to calculate the rate of total protein synthesis from the amino acid flux. On the other hand, the loss of radioactivity by ${ }^{14} \mathrm{CO}_{2}$ formation during infusion represents a source of error in the calculation of total protein synthesis which acts in opposite directions. This value is not known for leucine and lysine in pigs, but it is unlikely to compensate the error introduced by the low tissue specific activities. However, the values for leucine and lysine flux, presented in Table 3 are surprisingly constant among the individuals. The lysine flux seemed to be higher in rats than in pigs. The values reported for rats by Waterlow \& Stephen (1967, I968) were found to be approximately $700 \mu \mathrm{mol}$ lysine $/ \mathrm{kg}$ per h corresponding to $2.45 \mathrm{~g} / \mathrm{kg}$ per d.

For leucine flux no reference values are available. The flux for both amino acids was greater than the rate of intake from food. It follows that part of the flux was derived from intracellular protein breakdown and re-utilization. This finding is in agreement with observations made in man and rats (Millward, Garlick, James et al. 1976).

With regard to the precursor of amino acids for protein synthesis, the problem has been vigorously debated in recent years. Some investigators suggest that amino acids from an extracellular precursor pool may move directly into the synthetic machinery (Kipnis, Reiss \& Helmreich, 196I; Hider, Fern \& London, 1969, I97I; Fern, Hider \& London, 197I; London, 1972; Venrocij, Poort, Kramer \& Jansen, 1972). However, other investigators have concluded that the intracellular pool or some portion of it, represents the true source of amino acids (Tsukada, Moriyama \& Lieberman, 197I ; Alpers \& Thier, 1972; Fern \& Garlick, 1973, 1974; Li, Fulks \& Goldberg, 1973).

Airhart et al. (1974) and Vidrich, Airhart, Bruno \& Khairallah (1977) proposed a model which stipulated that both extracellular and intracellular amino acids contribute to a restricted compartment that 'funnels' amino acids towards protein biosynthesis. Of course there are tissue specific and amino acid specific differences which have to be investigated in the future. In our studies it has been shown that the rates of protein synthesis calculated from $\left[{ }^{14} \mathrm{C}\right]$ leucine and $\left[{ }^{14} \mathrm{C}\right]$ lysine intracellular specific radioactivities of the free amino acids were more consistent than those calculated from the specific radioactivities of the plasma free amino acids (Table 4). Therefore the rates of protein synthesis were calculated from the specific radioactivities of tissue amino acids. The rates of protein synthesis in pig muscle $(8 \cdot \mathrm{I} \% / \mathrm{d})$ are in the range of values reported for rats (Garlick et al. 1973; Millward et al. 1974a, $b$; Millward et al. 1975; Millward, Garlick, James et al. 1976). The fractional synthesis rate for liver proteins (I I $5 \% /$ d) is nearly double that of rats (Millward \& Garlick, 1972; Garlick et al. 1973; Millward, Garlick, James et al. 1976). They are also higher than those estimated by Garlick et al. (1976) in pigs. However, the difference in body-weight and age of animals used in our experiment ( $30 \mathrm{~kg}$ body-weight) and that of Garlick et al. (1976) (75 $\mathrm{kg}$ body-weight) should be mentioned. The greater error in calculating the absolute rate of synthesis is possible in the instance of the liver because the intracellular specific radioactivities of free leucine and lysine in this tissue are only 22 and II \% of the values for plasma. Therefore the danger of over-estimating the protein synthesis rate using the intracellular specific radioactivity of the free amino acids is high. Moreover, the true rate-constant for increase in specific radioactivity of the free amino acids in this pool is not known, as has been explained previously. 
The values for intestinal tissues show a tendency for the protein synthesis rate to be higher in the upper than in the lower part of the intestine. Our results for pigs suggest a half-life of protein synthesis in the small intestine of $1.5 \mathrm{~d}$ and in the large intestine of $2 \cdot \mathrm{I} d$. In earlier experiments with rats we found values for the half-life for protein breakdown in the small and large intestine of $\mathrm{I} .6$ and $2.6 \mathrm{~d}$ respectively (Simon, Bohley, Hückel, Münchmeyer \& Bergner, 1976).

It is very difficult to estimate the protein synthesis rate of the pancreas. The results obtained with $\left[{ }^{14} \mathrm{C}\right]$ leucine and $\left[{ }^{14} \mathrm{C}\right]$ lysine are quite different. In addition, results relate mainly to the rate of synthesis of the 'fixed' pancreas proteins. But the excretion of labelled pancreatic proteins into the gut is very rapid (Bergner, Bergner \& Simon, 1976, 1977) and these proteins are more highly labelled than the proteins 'fixed' in the tissue (Simon, Bergner \& Bergner, unpublished results). The total release of proteins from pancreas has been reported to be $19 \mathrm{~g} / \mathrm{d}$ in pigs (Corring, 1975). If the distribution patterns of radioactivity of protein at the end of infusion among the tissues are compared with the rates of protein synthesis it can be seen (Table 5) that the specific radioactivity of amino acids in protein is a poor indicator of the rate of protein synthesis. This is because the incorporation of radioactivity into proteins is closely related to the specific radioactivities of the amino acid precursor pool, which is determined to a large extent both by the pool size of the amino acid under consideration (Perry, 1975; Simon, Münchmeyer et al. 1976) and by the metabolic and catabolic pathways occuring in tissues (Garlick, I969).

It is concluded that the calculation of protein synthesis rate in pig tissues using the constant-infusion method of labelled amino acids and the model described seems to be a suitable tool for studies of this species.

\section{REFERENCES}

Airhart, J., Vidrich, A. \& Khairallah, E. A. (1974). Biochem. J. 140, 539.

Alpers, D. H. \& Thier, S. O. (1972). Biochim. biophys. Acta 262, 535.

Bergner, H., Bergner, U. \& Simon, O. (1977). Arch. Tierernährung 27, 173.

Bergner, U., Bergner, H. \& Simon, O. (1976). Arch. Tierernährung 26, 61 2.

Corring, T. (1975). Annls biol. anim. Biochim. Biophys. 15, I I5.

Fern, E. B., Hider, R. C. \& London, D. R. (1971). Eur. J. clin. Invest. r, 211.

Fern, E. B. \& Garlick, P. J. (1973). Biochem. J. 134, II 27.

Fern, E. B. \& Garlick, P. J. (I974). Biochem. J. I42, 413.

Garlick, P. J. (1969). Nature, Lond. 223, 6I.

Garlick, P. J., Burk, J. L. \& Swick, R. W. (1976). Am. J. Nutr. 230, 1108.

Garlick, P. J., Millward, D. J. \& James, W. P. T. (1973). Biochem. J. r36, 935.

Harenza, J., Wojtatowicz, Z. \& Zouner, H. (1975). In Chemia w Produkcji Zwierzecej [B. Wydawnicze, editor]. Warsaw: Chemia.

Henriques, O. B., Henriques, S. B. \& Neuberger, A. (1955). Biochem. J. 60, 409.

Hider, R. C., Fern, E. B. \& London, D. R. (1969). Biochem. J. x14, I 7 I.

Hider, R. C., Fern, E. B. \& London, D. R. (1971). Biochem. J. 221, 817.

Kipnis, D. M., Reiss, E. \& Helmreich, E. (196I). Biochim. biophys. Acta 5I, 519.

Li, J. B., Fulks, R. M. \& Goldberg, A. L. (1973). J. biol. chem. 248, 7272.

London, D. R. (1972). Proc. Nutr. Soc. 31, 193.

Millward, D. J. \& Garlick, P. J. (1 972). Proc. Nutr. Soc. 31, 157.

Millward, D. J., Garlick, P. J., James, W. P. T., Sender, P. M. \& Waterlow, J. C. (1976). Publ. Eur. Ass. Anim. Prod. no. I6.

Millward, D. J., Garlick, P. J., Nnanyelugo, D. O. \& Waterlow, J. C. (1976). Biochem J. 156, I85.

Millward, D. J., Garlick, P. J., Stewart, R. J. C., Nnanyelugo, D. O. \& Waterlow, J. C. (1975). Biochem. J. r5o, 235 .

Millward, D. J., Nnanyelugo, D. O. \& Garlick, P. J. (1974a). Proc. Nutr. Soc. 33, 55A.

Millward, D. J., Nnanyelugo, D. O. \& Garlick, P. J. (1974b). Proc. Nutr. Soc. 33, I 5 A.

Perry, B. N. (1975). J. agric. Sci., Camb. 84, 191 .

Simon, O., Bohley, P., Hückel, C., Münchmeyer, R. \& Bergner, H. (1976). Arch. Tierernährung $26,307$.

Simon, O., Münchmeyer, R., Bergner, H. \& Zebrowska, T. (1976). Arch. Tierernährung 26, 599.

Tsukada, K., Moriyama, T. \& Lieberman, J, (1971). J. Biochem., Tokyo 70, 172. 
Venrocij, W. J., Poort, C., Kramer, M. F. \& Jansen, M. T. (1972). Eur. J. Biochem. 30, 427. Vidrich, A., Airhart, J., Bruno, M. K. \& Khairallah, E. A. (1977). Biochem. J. 162, 257.

Waterlow, J. C. (1967). Clin. Sci. 33, 507.

Waterlow, J. C. \& Stephen, J. M. (1967). Clin. Sci. 33, 489.

Waterlow, J. C. \& Stephen, J. M. (I968). Clin. Sci. 35, 287. 